\title{
Small Firm Internationalization - A Developing Country Perspective
}

\author{
Tendy Matenge \\ Department of Marketing, Faculty of Business, University of Botswana \\ 4775 Notwane Rd, Gaborone, Botswana \\ Tel: +267-355-4727 E-mail: tendy.matenge@mopipi.ub.bw; m_tendy@yahoo.com
}

Received: Septemeber 15, 2011

doi:10.5430/ijba.v2n4p103
Accepted: September 29, 2011 Published: November 21, 2011

URL: http://dx.doi.org/10.5430/ ijba.v2n4p103

\begin{abstract}
This study investigates small firm internationalization from a developing country perspective. Despite the vast literature on small firm internationalization, the differences that exist between developing countries and developed countries remain unexplored. Therefore, current theories are influenced by processes and practices in developed countries, which are then applied blindly to developing countries. This study therefore asks: What are the factors that owners/managers in developing countries understand to influence the scope and pace of internationalization of their small firms?
\end{abstract}

An interpretive approach is adopted to explore the factors that influence internationalization of small firms from developing countries. Consequently, case data from four Botswana firms were collected and analyzed.

The literature review and case studies are used to propose a framework of a small firm internationalization from a developing country. The framework identifies major factors that influence small firm internationalization in this context as being; nationallentrepreneurial culture, government policies, networks, innovative products, market knowledge and commitment.

Keywords: Small Firm Internationalization, Developing Countries, Entrepreneurship, International Business

\section{Introduction}

As barriers to internationalization continue to fade, and while powerful internationalization of production and marketing continue to thrive all over the world, firms from developing countries realize that competing globally is not an option but an economic imperative (Rutashobya \& Jaensson, 2004). This is further enhanced by their governments' need to attain millennium development goals by creating environments that will stimulate small firms' competitiveness in the existing globalised export markets (World Bank, 1991).

The subject of firm internationalization has elicited much comment in the marketing, exporting, and international business literature (Chetty \& Campbell-Hunt, 2003; Crick \& Chaudhry, 1997; Oviatt \& McDougall, 2005). One of the issues of particular interest is the applicability of the various internationalization theories to the small firms' expansion into foreign markets.

Even though the internationalization of firms has been studied extensively (Rutashobya \& Jaensson, 2004), the internationalization of small firms, especially from developing countries has received very little attention from academic inquiry. This study, therefore, investigates small firm internationalization from a developing country perspective.

\subsection{Why Small Firms and Developing Countries Matter for Internationalization}

The export behavior and internationalization processes of small firms have been the topic of widespread research efforts in the past 30 years (Rasmussen \& Madsen, 2002). The interest in the research area corresponds very well with the increasing importance of international trade which has fostered a rise in many forms of international business. So, for small firms as well as governments, the research topic has been highly relevant.

Environmental conditions such as changing industry and market conditions and the internationalization of industry competition create the ideal context for small firm internationalization (Chetty \& Campbell-Hunt, 2003). Furthermore, the firm's customers, some being international, and the intense competition from imports in the firm's domestic market induce firms to envisage their business in global terms (Oviatt \& McDougall, 1995). Moreover, the liberalization of trade and advances in technology in the areas of telecommunications, especially the internet, provide easy access to worldwide customers, distributors, network partners, and suppliers. 
Despite the potential impact that small firms from developing countries may have on broader international business, previous internationalization studies have concentrated on firms from OECD economies and have failed to take into account the developing countries, where local firms face severe competition from multinational enterprises and where the need for internationalization is eminent, albeit slowly forthcoming. Therefore, research in addressing internationalization in developing countries is worth undertaking. In addition, internationalization can be the engine for individual small firm's growth and a major economic contributor in respective developing countries (Ariyo, 2008; Botswana Institute for Development Policy Analysis, 2000).

\section{Literature Review}

Firm internationalization perspectives in general have evolved and changed over the years, however, small firm internationalization is recent, and is a phenomenon which has occurred as a consequence of opening markets through deregulation, and new competitive spaces emerging. Regardless of the continuous and evolving interest, thoughts on small firm internationalization have been dominated by the behavioral theories, and of recent the entrepreneurial theories.

There are two generally accepted behavioral theories of internationalization: The Uppsala internationalization model (Johanson \& Vahlne, 1977) and the Innovation model (Cavusgil, 1980). Both models are often referred to as the stages/gradualist models because they propose that internationalization occurs in incremental steps. However, in internationalization literature the most used models representing behavioral and entrepreneurial theories are the Uppsala and Born global, respectively.

\subsection{The Uppsala Model}

The underlying assumption of the Uppsala model is that as firms learn more about a specific market, they become more committed to it by investing more resources into it. The model purports that the firm goes gradually through the stages of internationalization (Johanson \& Wiedersheim-Paul, 1975). In this gradualist view, firms make their export debut when they have a strong domestic market base. The choice of markets also occurs in stages; firms begin to export to a market that has a close psychic distance, and then they expand export sales into markets that have increasingly greater psychic distance (Johanson \& Vahlne, 1977).

However, the Uppsala view fails to explain why some firms internationalize faster than others, and what drives internationalization. Furthermore, it has been found that the Uppsala model fails to fully explain the nature and character of small firms' international involvement.

\subsection{The Born Global Model}

The entrepreneurial view, represented by the born global perspective of small firm internationalization provides a more contrasting outlook of internationalization to the gradualist approach. The born global perspective purports that firms do not internationalize gradually but rather enter international markets soon after their inception. The proponents of this view argue that such small firms may not even have sales in their home markets (Rennie, 1993; Oviatt \& McDougall, 1994; Knight \& Cavusgil, 1996), and are thus contradicting the gradualist model. In addition, small firms that internationalize at inception/early perceive the world as one market. They perceive the international market as providing opportunities rather than obstacles (Madsen \& Servais, 1997) and therefore the main focus of a born global firm is growth through international sales.

The perspective gives insight into the factors that may lead to a small firm internationalizing. Despite this insight, it is limited as it only proposes to explain internationalization of a born global firm. Furthermore, the attempt is limited to the factors that may lead to internationalization, and appears to view internationalization as entering a single market, and not a continuous process. It would be expected that the firm's experiences as it internationalizes would affect its activities and processes in future as it seeks to enter into more foreign markets. Practitioners and policy planners, especially in developing countries, could benefit from the identification of a feasible path to small firm internationalization, possibly an accelerated path, which enables the planning of strategic decision making, so that firms can benefit from rapid entry into promising international markets.

These two schools of thought have over the years been advancing on parallel fronts, inviting seminal work by Coviello and McAuley (Coviello \& McAuley, 1999) that called for an integrated approach and more qualitative studies in the field of small firm internationalization. 


\section{Research Method}

\subsection{Case Study Design}

The case study is "an empirical enquiry that investigates a contemporary phenomenon within its real life context, especially if the boundaries between the phenomenon and context are not clearly evident" (Yin, 2003).

Following other studies illustrating small firm internationalization, (Chetty \& Campbell-Hunt, 2003; Sharma \& Blomstermo, 2003; Andersson \& Wictor, 2003), the researcher chose the case study method as a particularly valuable technique in this context. This study involved in-depth case study analysis of four Botswana small firms that illustrate successful internationalization, representative of the two internationalization theories. It was useful to use four cases as multiple case-based researches serve as a basis for building and refining new theoretical explanations of the phenomenon being researched (Yin, 1993; Yin, 2003).

In addition, reasonable conclusions of the results of the several cases being used to other contexts with similar theoretical conditions can be obtained. Furthermore, Eisenhardt (Eisenhardt, 1989) has suggested that multiple case approaches encourage researchers to study patterns that are common in cases and avoid chance associations.

The study typically combined data collection methods such as archives, interviews, questionnaires, and observations. It is typical of theory building researchers to combine multiple theory building methods. The triangulation made possible by multiple data collection methods provided stronger substantiation of constructs and hypotheses (Eisenhardt, 1989).

The sampling frame consisted of small firms across a range of industries; however, all of the small firms were affiliates of Botswana Export Development and Investment Authority (BEDIA), as it provided convenience. Cases were chosen based on their ability to inform the research question, and advice was sought from key informants, as to who would be able to best inform the research question. To be consistent with previous research on small firms (Zacharakis, 1997) all firms in the purposeful sample were small, and independently managed.

\section{Findings}

Factors that emerged in the study as influencing internationalization regardless of the pattern are:

- Government role and trade relations

- Differentiated/Innovative product offering

- $\quad$ Market knowledge and market commitment

- Entrepreneurial culture

- Prior international experience

\subsection{Government Role and Trade Relations}

It emerged that small firms need to be assisted by their governments as they venture into the international market. The government's role is viewed as primarily facilitating trade relations between small firms and foreign countries. It has been established that small firms find it challenging to market their products and at the same time deal with foreign government bureaucracies.

“...we could market our products in Australia, but the government restrictions there are too much, it's better to deal with UK even though the uptake of our products is very slow...”

The sentiments were consistent across the different internationalization patterns. As a result, some firms scaled down their international participation as the local market seemed more lucrative.

"...there was no incentive, because the firms in developed countries get export rebates...we survived for 13/14 years without export rebates from government, but ultimately we had to surrender..."

In addition to difficult trade relations, it emerged that small firms take unreasonably long to get established in the international market as the owners/managers have to use their own savings to set up their firms and eventually internationalize. The process is made more difficult by the fact that competing firms from developed countries get export rebates from their governments.

“...we built capital to start buying stock and eventually used that capital to integrate backwards into manufacturing...I didn't have capital, instead of going to the bank or investors I built up my own funds over a period of time...”

\subsection{Differentiated/Innovative Product Offerings}

Small firms that offer innovative products fared well in the international market as compared to the small firms that offer fairly generic products. The performance of these firms was not dependent on the time they took to internationalize. 
Therefore, a differentiated product offering proved to be an important factor in determining the eventual performance of the small firms.

“...we don't aim to export, it is a unique product that necessitates our exporting...',

“...we produce a nontraditional product. We had to do a lot of research to find the locations of the industries that may use our product..."

“...we keep up to international standards, so we offer state of the art...as the markets change we also adapt...”

In contrast, the firms that offered generic products eventually scaled down their production, concentrating on the local market. However, all the owners/managers strongly believe in the importance of a differentiated and innovative product offering for the firm to be successful.

\subsection{Market Knowledge and Market Commitment}

Internationally successful small firms spent time studying their potential markets and had in-depth knowledge by the time they decided to internationalize.

“...we started by doing desktop research to find out who is using which products. After that we made contact with end users ...we had a lot of meetings with potential customers, and eventually agreements were made...”, and

“...the markets we were looking at consistently changed over the years..."

Despite how long it took the successful small firms to initiate exporting they did a lot of research on the markets of interest, which is contrary to the firms that are not successful internationally. "...we haven't done much active market research as such; we just rely on word of mouth..." The firm exports to the UK where its products are not "appreciated" instead of heavily exporting to Australia and the United States where there is much more "appreciation" for their products. In-depth knowledge of the market was found to be important in the performance of a small firm in the international market. Unsuccessful firms were found to be not highly knowledgeable of their markets. They were also ignorant of any future potential markets as they eventually failed to have any impact in their international operations. Their commitment to the international market was questionable. In contrast, successful firms were found to be highly knowledgeable and committed to the market. They invested in the international markets, and have manufacturing firms in various countries.

\subsection{Entrepreneurial Culture}

The level of entrepreneurial culture varied across owners/managers. However, it emerged that the owners/managers that offered differentiated products were more entrepreneurial than their counterparts who offered generic products. The level of entrepreneurial culture was determined by how the firms approached the international market and their eventual international performance. This entrepreneurial culture is not only limited to owners/managers, but is also reflected by the staff. It can however, be argued that entrepreneurial culture is also determined by the national culture (Shane, 1992).

"...few are trained to be entrepreneurs. The culture is that, one performs well academically and goes to university and eventually gets a good job. While the culture is changing, and courses on entrepreneurship have been introduced, when I went to school that was not the case; the culture of entrepreneurship was none existent..."

It emerged that institutional characteristics, culture, education, and the social culture of the nation all played a part in shaping the small firm's entrepreneurial outlook. It was found out that the small firms that were internationally unsuccessful rarely trained their employees and the owners/managers did not achieve high levels of education or were in their old age.

Whereas those that were successful took pride in the work they did and viewed themselves as playing an important role in economic development. The owners/managers of the firms acknowledged that it is not only the attitude of owners/managers that impact on the performance of the small firm in the international market, but also those of employees. "...we need to employ someone who would be dedicated enough and generate their own income...and they are not easy to find...”

\subsection{Prior International Experience}

All the owners/managers of the small firms had no prior international experience. Despite this lack of experience, even the firms that are not highly successful managed to export for years before failing. Even though the owners/managers appreciate the impact that prior knowledge may have on how they went about exporting they do not believe that it is entirely necessary. 
The product is seen as the driving force of internationalization. Therefore, in that context the pattern of internationalization does not matter, as the time it takes for a small firm to internationalize is dependent on the type of product the firm offers.

“...why would you aim to export? You start a business to provide a service or product and make a profit...if an export market becomes attractive for you, then you go for it, but you need to have a product or service to offer. So start with a product or service, identify a market for that product...have the right product for the market..."

“...we are currently looking at developing smaller products to export to markets farther afield than Africa...”

In this case the product also determines the costs that the firm would incur in trying to export. In essence, there are products that are worth exporting and others are better sold to the local market.

Furthermore, even as born global, owners/managers believe that it is wise to develop a strong local market before going international as "on the export market you cannot make mistakes, you don't have too many chances. It is a lot more difficult when you do not have a local market...”

\section{Conceptual Framework and System of Relationships}

The central proposition of this proposed framework is that firms internationalize at differing paces to differing markets due to the differing entrepreneurial culture in their respective countries, their government policies, and how differentiated/innovative the products on offer are, as depicted in Figure 1.

\subsection{National Culture}

Researchers are beginning to suggest, and study, the potential between national culture, using national boundaries, as a proxy for cultural boundaries, and the propensity to support firm internationalization (Jones \& Davis, 2000; Shane, 1992; Nakata \& Sivakumar, 1996). The implications of these studies and models is the suggestion that certain cultural profiles have better propensity to support innovation activities and in consequence impact on the internationalization prospect of firms in that particular cultural setting.

During the analysis of the case data, it was found that culture in developing countries did not encourage setting up of small firms and general innovation in an organizational set-up. This culture inhibited small firms in their international activities as the owners/managers tend to be skeptical of growing their firms beyond their National borders. The firms that internationalized traded mostly within the region and only one internationalized to countries outside the region.

The case data is further supported by a Global Entrepreneurship Monitor (GEM) report that found that the environment in which individuals socialize influences their entrepreneurial tendencies (Maas \& Herrington, 2006). The culture in developing countries is such that there is a sense of entitlement and an expectation that big businesses, government and others should create jobs, rather than that one can create one's employment. Fear of failure is high because society is hard on those legitimate businesses that fail. Given that exporting is a risky process that often involves cycles of failure, a harsh attitude to failure would be a limiting factor to entrepreneurial and export development.

Following the foregoing discussion it is therefore argued that national culture plays a critical role in the internationalization of small firms in developing countries as it influences leadership style, firm vision, and firm strategy, and it is proposed that:

Proposition 1: The scope, pace, and extent of small firms' internationalization process will differ between developing and developed countries because of their different cultural orientations.

\subsection{Government Policy}

Nurturing an entrepreneurial culture and facilitation by governments in small firm internationalization provides a solid ground on which small firms in developing countries can compete and grow internationally. Analysis of the cases showed that small firms failed in the initial stages of their internationalization process as a result of lack of a solid base from which to take off, primarily as a result of poor government facilitation.

It has been established that the level of entrepreneurship differs strongly across countries. This variance is related to the levels of economic development, but also has to do with diverging demographic, cultural, and institutional characteristics (Blanchflower, 2000). The governments in developing countries need to play an active role in nurturing this culture from a young age by providing mentoring programs to small firms.

It has been found that in the long run government policies would have more impact on entrepreneurial dynamics through the gradual evolution of culture and institutions (Wennekers, Van Wennekers, Thurik, \& Reynolds, 2005). Developing countries may be better off investing in the development of management qualities of their population and investment in the growth of their small firms. Governments need to further play a facilitative role in ensuring that small firms compete 
in an environment that gives them a chance to survive. Trade relations between countries should be strong and accommodative of small firms. Moreover, governments should be in a position to provide financial assistance to small firms that face 'unfair competition' from firms that receive assistance from their governments. The case data revealed that small firms that did not do well in the international market faced a lot of competition from firms that received financial assistance from their governments. This results in firms from developing countries being under-cut in pricing.

It is therefore, argued that entrepreneurial culture and government policies are critical to internationalizing small firms, and it is proposed that:

Proposition 2: Government policies that are supportive of small firms are positively related to good performance of small firms in the international market.

Proposition 3: Government policies that are supportive of small firms are positively related the entrepreneurial culture.

\subsection{Entrepreneurial Culture}

Analysis of the cases revealed that lack of entrepreneurial culture in developing countries results in small firms that are not competitive in the international market. Furthermore, the government role in assisting small firms in the international market has not been forthcoming. Albeit that an entrepreneurial culture has to be nurtured from a young age.

The positive impact of a society’s general culture was further illustrated by (Knack \& Keefer, 1997), when they brought to the fore the notion of 'social capital'. They purport that culture's relationship to economic growth is especially large in developing countries, which may be attributable to the less well-developed financial sectors, insecure property rights, and unreliable enforceable contracts. The development of an entrepreneurial culture is very important in the internationalization of small firms in developing countries.

In most of the cases, it was clear that small firms succeeded based on the entrepreneurial culture of the owners/managers. However, the culture has to be inclusive of employees as they play a pivotal role in the quality of production and service delivery. It is therefore proposed that:

Proposition 4: Entrepreneurial culture is positively related to differentiated/innovative products.

\subsection{Product (Differentiated/Innovative)}

Product differentiation is an important concept in the context of growth and international trade. According to modern trade theories and empirical evidence, product differentiation in open economies is the most important source for the export performance (Kang, 2008; Porter, 1998). Differentiated products have a longer life than either referenced priced or homogenous goods (Kang, 2008).

For owners/managers of small firms in developing countries the aim is not 'to go international', but to produce a product that will prompt them to sell internationally. In the study, small firms that are not successful in the international market have a product that is not differentiated. Such firms ended up focusing on the local market to sustain their performance.

If the product is highly differentiated/innovative the learning and commitment made by the firm tends to be high. However, small firms that provide homogenous products tend not to be committed to the international markets as they can compete favorably in the local market. It is therefore, proposed that:

Proposition 5: Innovative/Differentiated products are positively related to the good performance of small firm internationalization.

\subsection{Market Knowledge, Commitment and Prior Experience}

Although prior international experience would come in handy, is not a prohibiting factor as evidenced by those owners/managers from data cases who started their firms without any international experience. They had as much chances of success as those that had prior experience. However, international experience gives one assurance and the benefit of hindsight, therefore prior experience would be beneficial in knowing what information to look for and which contacts one needs. In essence, expertise in internationalization is built with experience rather than beforehand.

However, the knowledge structures of top management based on their experience and learning in domestic markets before starting any international activities mediate the relationship between domestic resource diversity, domestic action complexity, and the firm's international commitments (Nadkarni \& Perez, 2007). This ability to adapt domestic products and strategies to foreign markets can cosiderably reduce the barriers to internationalization efforts (Tallman, 1991). It is therefore proposed that:

Proposition 6: Prior international experience has a limited impact on the firm’s market knowledge.

Proposition 7: Prior international experience has a limited impact on the firm's market commitment. 
The contention that firms use their domestic mindset to evaluate their new environment is well recognized in the organization learning literature (March \& Simon, 1958; Martins \& Kambil, 1999). These are knowledge structures that owners/managers had before starting any international activity, which are based mainly on their cumulative experience and learning in their home markets. Mindsets act as filters through which some international markets gets noticed whereas others are discarded. Although the importance of the international experiential knowledge is not disputed, it is proposed that:

Proposition 8: Market knowledge is positively related to the small firm's market commitment and vice versa.

Proposition 9: Market knowledge and market commitment are positively related to the firm's internationalization process.

\subsection{Networking}

Market knowledge may encourage a sufficient willingness to take the risks that are inherent in the development of differentiated/innovative products that may facilitate a wider scope of internationalization. Innovation has been suggested as a possible link between market orientation and firm performance (Menguc \& Auh, 2006), where innovation requires external learning (which includes market learning and network learning for new technology acquisitions) and internal experimental learning (which includes research and development) (Arora \& Gambardella, 1990).

The combination of these factors, despite the pattern of internationalization, determine the pace, scope, and extent small firm internationalization from a developing country and possibly its subsequent international market performance in international markets. The networks and market knowledge coupled with innovative products ensure that firms stay ahead of their competitors in the market.

The strategies employed by the firm would determine the resources that the firm commits to the market as well as the marketing activities the firm engages in. The dynamics of the market requires the internationalizing firm to continuously learn about its current market and the markets that the firm would want to enter in future. This process becomes continuous for the current market as well as for future markets, as the firm's current experiences and knowledge determine product development and markets of future interest. In consequence, the markets of future interest would determine the products that the firm would produce, and the process continues. The final propositions become:

Proposition 10: Networking is positively related to the small firm's market knowledge.

Proposition 11: The experience gained in the internationalization process is positively related to the small firm's internationalization scope, pace, and extent.

\section{Concluding Remarks}

This study has investigated small firm internationalization by re-visiting the themes that once occupied the attention of internationalization researchers, in particular the Uppsala and Born global scholars. The main research question was: What are the factors that influence scope and pace internationalization of small firms in developing countries? The point of departure in investigating this question was the understanding of owners/managers from developing countries, and their experiences of internationalization.

The findings from this study challenge existing explanations by bringing a perspective that has been ignored to the fore. Firstly, that internationalization of firms in developing countries is approached differently from that of firms from developed countries and therefore explanations of the phenomenon is different. Small firms from developing countries have far more challenges that they face as they internationalize than firms from developed countries. Unfortunately current theories seem to overlook this factor and tend to generalize internationalization based on findings from developed countries.

Secondly, although the findings reveal the already acknowledged patterns of internationalization (born global and stages), these seem not to be determining factors of the scope, and extent of a firm's internationalization process. Such fundamental factors as entrepreneurial culture, government role and trade relations are more influential than it has been previously acknowledged. Consequently these two factors serve as a foundation for a small firm's internationalization process.

A developing country perspective of small firm internationalization not only challenges the current explanations, but also highlights the different factors and conditions that small firms in developing countries face as they struggle in the international market. Furthermore, the framework merges the process and entrepreneurial theories and move beyond the patterns that firms assume in internationalizing to reveal the similarities that are evident regardless of the differing patterns. 


\section{Acknowledgements}

The author would like to thank Dr. Martie-Louise Verreynne for the guidance provided during the early stages of the study and the two anonymous reviewers for their thoughtful comments.

\section{References}

Andersson, S., \& Wictor, I. (2003). Innovative Internationalisation in New Firms: Born Globals—the Swedish Case. Journal of International Entrepreneurship , 249-276. http://dx.doi.org/10.1023/A:1024110806241

Ariyo, D. (2008, January 23). Small Firms are the Backbone of the Nigerian Economy. Retrieved August 26, 2010, from Africa Economic Analysis: http://www.africaeconomicanalysis.org/articles/gen/smallhtm.html

Arora, A., \& Gambardella, A. (1990). Complemetary and External Linkages: Strategies of the Large Firm in Biotechnology. Journal of Industrial Economics , 361-379. http://dx.doi.org/10.2307/2098345

Blanchflower, D. G. (2000). Self-Employment in OECD Countries. Labor Economics 7 , $471-505$. http://dx.doi.org/10.1016/S0927-5371(00)00011-7

Botswana Institute for Development Policy Analysis (BIDPA). (2000). The New Policy on Small, Medium and Micro Enterprises. BIDPA Briefing , pp. 1-4.

Chetty, S. K., \& Campbell-Hunt, C. (2003). Paths to Internationalisation Among Small-to-Medium-sized Firms: A Global Versus Regional Approach. European Journal of Marketing , $796-820$. http://dx.doi.org/10.1108/03090560310465152

Crick, D., \& Chaudhry, S. (1997). Small Businesses' Motives for Exporting: The Effect of Internationalization. Journal of Marketing Practice: Applied Marketing Science, 156-70. http://dx.doi.org/10.1108/EUM0000000004340

Eisenhardt, K. M. (1989). Building Theories from Case study Research. Academy of Management Review , 532-50. http://dx.doi.org/10.2307/258557 / http://dx.doi.org/10.5465/AMR.1989.4308385

Johanson, J., \& Vahlne, J. (1977). The Internationalization Process of the Firm - A Model of Knowledge Development and Increasing Foreign Market Commitments. Journal of International Business Studies , $23-32$. http://dx.doi.org/10.1057/palgrave.jibs.8490676

Johanson, J., \& Wiedersheim-Paul, F. (1975). The Internationalization of the Firm - Four Swedish Cases. Journal of Management Studies , 305-322. http://dx.doi.org/10.1111/j.1467-6486.1975.tb00514.x

Jones, G. K., \& Davis, H. J. (2000). National Culture and Innovation: Implications for Locating Global and Research and Development Operations. Management International Review .

Kang, K. (2008). How Much Have Been the Export Products Changed from Homogeneous to Differentiated? Evidence from China,Japan, and Korea. China Economic Review , 128-37. http://dx.doi.org/10.1016/j.chieco.2007.06.001

Knack, S., \& Keefer, P. (1997). Does Social Capital have an Economic Payoff? A Cross Country Investigation. Quarterly Journal of Economics , 1251-288. http://dx.doi.org/10.1162/003355300555475

Knight, J., \& Cavusgil, T. S. (1996). The Born Global Firm: A Challenge to Traditional Internationalization Theory. Advances in International Marketing , 11-26.

Maas, G., \& Herrington, M. (2006). Global Entrepreneurship Monitor: South African Report. Cape Town: University of Cape Town.

Madsen, T. K., \& Servais, P. (1997). The Internationalization of Born Globals: An Evolutionary Process? International Business Review , 561-83. http://dx.doi.org/10.1016/S0969-5931(97)00032-2

March, J., \& Simon, H. (1958). Organizations. Wiley: New York.

Martins, L., \& Kambil, A. (1999). Looking Back and Thinking Ahead: Effects of Prior Success on Managers' Interpretations of New Information Technologies. Academy of Management Journal , 652-71. http://dx.doi.org/10.2307/256986

Menguc, B., \& Auh, S. (2006). Creating a Firm Level Dynamic Capability Through Capitalizing on Market Orientation and Innovativeness. Journal of Academy of Marketing Science , 63-73. http://dx.doi.org/10.1177/0092070305281090

Nadkarni, S., \& Perez, P. D. (2007). Prior Conditions and Early International Commitment: The Mediating Role of Domestic Mindset. Journal of International Business Studies , 160-76. http://dx.doi.org/10.1057/palgrave.jibs.8400248

Nakata, C., \& Sivakumar, K. (1996). National Culture and New Product Development: An Integrative Review. Journal of Marketing , 61-72. http://dx.doi.org/10.2307/1251888

Oviatt, B. M., \& McDougall, P. P. (1994). Toward a Theory of International New Ventures. Journal of International Business Studies , 45-64. http://dx.doi.org/10.1057/palgrave.jibs.8490193 
Oviatt, B. M., \& McDougall, P. P. (1995). Global Start-Ups: Entrepreneurs on a Worldwide stage. Academy of Management Executive , 30-44. http://dx.doi.org/10.5465/AME.1995.9506273269

Oviatt, B. M., \& McDougall, P. P. (2005). Defining International Entrepreneurship and Modeling the Speed of

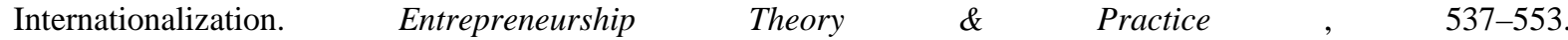
http://dx.doi.org/10.1111/j.1540-6520.2005.00097.x

Porter, M. E. (1998). Competitive Strategy:Techniques for Analyzing Industries and Competitors with a New Introduction. New York: Free Press.

Rasmussen, E. S., \& Madsen, T. K. (2002). The Born Global Concept. SME Internationalization and Born Globals Different European Views and Evidence - The EIBA Conference (pp. 1-27). EIBA.

Rennie, M. W. (1993). Global Competitiveness: Born Globals. The McKinsey Quarterly , pp. 45-52.

Rutashobya, L., \& Jaensson, J.-E. (2004). Small Firm's Internationalization for Development in Tanzania: Exploring the Network Phenomenon. International Journal of Social Economics , 159-72. http://dx.doi.org/10.1108/03068290410515484

Shane, S. A. (1992). Why Do Societies Invent More Than Others? Journal of Business Venturing , 29-46. http://dx.doi.org/10.1016/0883-9026(92)90033-N

Sharma, D. D., \& Blomstermo, A. (2003). The Internationalization Process of Born Globals: A Network View. International Business Review , 739-753. http://dx.doi.org/10.1016/j.ibusrev.2003.05.002

Tallman, S. (1991). Strategic Management Models and Resource-Based Strategies Among MNCs in a Host Market. Strategic Management Journal , 62-82.

Wennekers, S., Van Wennekers, A., Thurik, R., \& Reynolds, P. (2005). Nascent Entrepreneurship and the Level of Economic Development. Small Business Economics , 293-309. http://dx.doi.org/10.1007/s11187-005-1994-8

World Bank. (1991). World Bank Restructuring Economies in Distress. Washington DC.: The World Bank.

Yin, R. K. (1993). Application of Case Study Research. Newbury Park: SAGE.

Yin, R. K. (2003). Application of Case Study Research. Thousand Oaks: Sage Publications.

Zacharakis, A. (1997). Entrepreneurial Entry Into Foreign Markets: A Transaction Cost Perspective. Entrepreneurship Theory and Practice , 23-39.

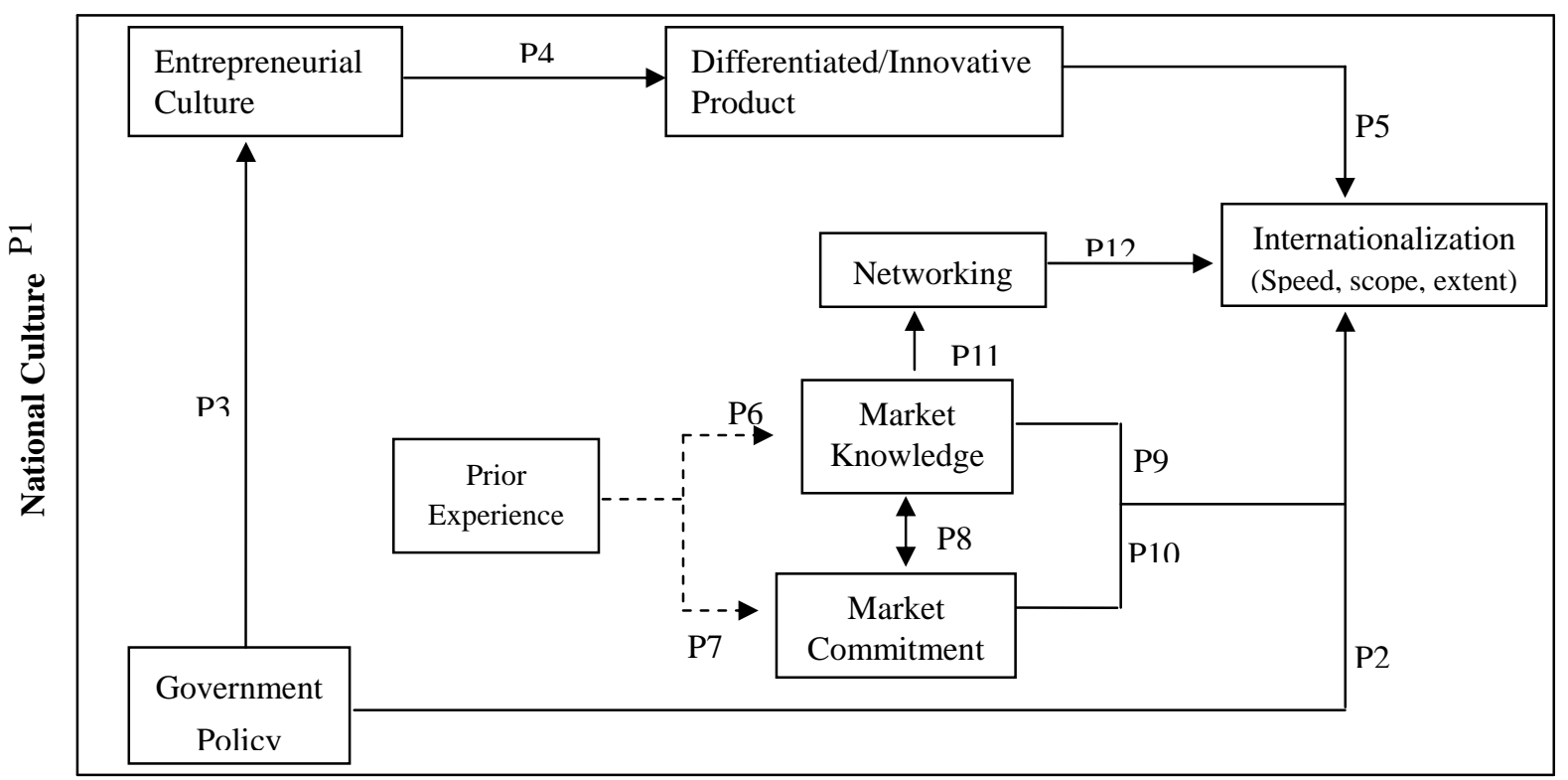

Figure 1. The Proposed Internationalization Process of a Small firm Framework: A Developing Country Perspective 